УДК 656.212.5

\title{
АНАЛІЗ ВІДОМИХ ПІДХОДІВ ДО РЕГУЛЮВАННЯ ШВИДКОСТІ СКОЧУВАННЯ ВІДЧЕПІВ
}

\author{
М.В. Квітковська
}

\section{АНАЛИЗ ИЗВЕСТНЫХ ПОДХОДОВ К РЕГУЛИРОВАНИЮ СКОРОСТИ СКАТЫВАНИЯ ОТЦЕПОВ}

\section{М.В. Квитковская}

\section{ANALYSIS KNOWN APPROACHES TO SPEED CONTROL SLIDE UNHOOK M.V. Kvitkovs'kyj}

Проаналізовано відомі принципи регулювання швидкості руху відчепів. Детально розглянуто вітчизняний $i$ закордонний досвід застосування технології частково безперервного регулювання. Наведено висновки фахівиів щодо підвищення ефективності сортувального процесу.

Ключові слова: сортувальна гірка, сортувальний прочес, принципи регулювання швидкості руху відчепів.

Проанализированы известные принципы регулирования скорости движения отиепов. Детально рассмотрен отечественный и зарубежный опыт применения технологии частично непрерывного регулирования. Приведены выводы специиалистов, касающиеся повышения эффективности сортировочного прочесса.

Ключевые слова: сортировочная горка, сортировочный процесс, принципь регулирования скорости движения отиепов.

The well-known adjusting principles of speed cuts movement were analysed. Domestic and foreign experience of technological application of partly continuous adjusting were detailly considered. The specialists' conclusions, concerning efficiency increases of sorting process were presented.

Keywords: sorting hump, sorting process, principles of speed cuts movement. 
Вступ. Серед найбільш розповсюджених технологій регулювання швидкості скочування відчепів $є$ технологія інтервально-прицільного гальмування. Реалізується вказана технологія за допомогою гальмових позицій (ГП) спускної частини і паркової гальмової позиції (ПГП). У функції І ГП входить інтервальне регулювання, II ГП, як правило, - інтервально-прицільне, ПГП - прицільне. Така технологія регулювання швидкості скочування відчепів, з одного боку, забезпечує потрібну інтенсивність сортувального процесу, а 3 іншого - не виключає пошкодження вагонів і вантажів, що перевозяться, та збоїв у роботі гірки.

Актуальність. Причинами негативних наслідків реалізації технології інтервальноприцільного гальмування $\epsilon$, в першу чергу, недоліки гальмових засобів, стан поздовжніх профілів колій, помилки гіркових операторів i автоматизованих систем управління, які не в повній мірі враховують чинники, що впливають на процес скочування відчепів. Незважаючи на те, що технологія інтервально-прицільного гальмування має найбільше поширення на залізницях світу і використовується вже майже сторіччя, їі удосконалення $є$ дуже актуальною задачею.

Аналіз досліджень i публікацій. Розробкою наукових підходів до регулювання швидкості скочування відчепів займались такі вчені як Бобровський В.І., Божко М.П., Буянова В.К., Муха Ю.А., Пилипченко П.А., Нагорний Є.В., Берестов I.В. та інші [1-8]. Основна увага в працях вказаних вчених приділялася задачі вибору раціональних режимів гальмування відчепів на спускній частині та оптимізації параметрів систем регулювання швидкості руху вагонів на підгіркових коліях. Розроблені вказаними вченими наукові положення базувались на результатах імітаційного моделювання. Загальним недоліком запропонованих моделей $\epsilon$ неповне урахування випадкових факторів.

Формулювання мети (постановка завдання). Метою даної роботи є визначення основних напрямків удосконалювання підходів до регулювання швидкості скочування відчепів на спускній частині i підгіркових коліях залізничних станцій України.

Основна частина дослідження. Слід відзначити, що наявність порівняно великого числа браків у роботі сортувальних гірок, що працюють за технологією інтервально- прицільного гальмування, в першу чергу пов'язана із застосуванням саме прицільного регулювання швидкості скочування відчепів на підгіркових коліях. Для зменшення кількості вказаних браків за кордоном впроваджуються системи комплексної автоматизації роботи гірки i підгіркового парку. При цьому на багатьох станціях замість технології прицільного гальмування використовується технологія примусового регулювання швидкості руху відчепів за допомогою канатнотягових вагоноосаджувачів (Німеччина, Японія), уповільнювачів-прискорювачів 3 лінійними двигунами (Японія), візків для прискорення і уповільнення швидкості відчепів (Франція), точкових (Англія, Німеччина, Швейцарія, Угорщина. Польща, Китай) i гвинтових (Швеція) уповільнювачів та інших пристроїв.

Технологія регулювання швидкості скочування відчепів точковими вагонними уповільнювачами (технологія так званого квазібезперервного регулювання) вперше була застосована на станції Ашчерч $у$ Великобританії в кінці $60-\mathrm{x}$ років минулого сторіччя, де на одній із сортувальних колій були встановлені уповільнювачі Dowty. Пізніше такі уповільнювачі було випробувано на станції Хол.

Незважаючи на суттєві переваги технології квазібезперервного регулювання (заповнення підгіркових колій без «вікон» i виключення пошкодження вагонів і вантажів), на даний момент точкові вагонні уповільнювачі мають обмежене розповсюдження, зокрема у Європі.

Найбільш показовим $\epsilon$ досвід застосування різних технологій регулювання швидкості руху відчепів на залізничних станціях Японії. Від технології прицільного регулювання японські фахівці відмовились ще в 1969 році. У цьому ж році на станції Такасаки була застосована технологія квазібезперервного регулювання швидкості скочування відчепів уповільнювачами Dowty, a у 1972 році точковими уповільнювачами Oleo модифікації Dowty на сортувальній станції Кинтонама. В 1974 році на станції Тойяма і в 1975 році на станції Сіогама примусове регулювання швидкості вперше було здійснено лінійними двигунами, а в 1980 році на станції Мусасино i в 1982 році на станції Васиномий - канатнотяговими вагоноосаджувачами 3 електропри- 
водом за досвідом Німеччини. На думку японських фахівців, останні забезпечують низькі капітальні i експлуатаційні витрати, стабільність і надійність роботи системи.

Як вже зазначалося вище, в СРСР теоретичні і експериментальні дослідження можливості застосування технології примусового регулювання швидкості руху відчепів на підгіркових коліях розпочав професор О.М. Долаберидзе. Продовжили ці дослідження його учні Є.В. Нагорний i I.В. Берестов [7, 8]. Окрім варіантів примусового регулювання ними було розглянуто варіанти комбінованого регулювання.

Слід відзначити, що на більшості залізничних станцій України основною перешкодою у застосуванні примусового регулювання швидкості руху відчепів за допомогою вагоноосаджуючих пристроїв $\epsilon$ складність метеорологічних умов, особливістю яких є періодичні сильні снігові замети. Таким чином, використання вказаних пристроїв у холодні періоди року не забезпечить стабільне функціонування вітчизняних СГ.

Застосування на залізничних станціях України технології квазібезперервного регулювання також $\epsilon$ достатньо проблематичним. По-перше, для іiі реалізації необхідно здійснити коштовну реконструкцію профілю гірки і підгіркових колій. Крутизна останніх повинна бути не менше $1,5 \%$ о. Подруге, потрібно створити відповідні умови для якісного технічного обслуговування точкових уповільнювачів, що також вимагає значних витрат на закупівлю випробувальних стендів, ремонтного і діагностичного устаткування. При відсутності таких умов відновлення працездатності закордонних уповільнювачів можливе тільки на заводах-виробниках. А вартість відновлення може сягати 50 \% вартості уповільнювача.

Звертає на себе також увагу проведений російськими фахівцями аналіз роботи точкових вагонних уповільнювачів на сортувальних гірках Угорщини. Так, на станції Ференцварош щомісячно вилучається 3 колії до тисячі таких уповільнювачів, пошкоджується за календарний рік не менше 10 вагонів i переробляється не більше 3000 вагонів на добу при паспортній переробній спроможності 4000 вагонів на добу. Однією з причин використання вказаної спроможності на $75 \%$ є конструктивне обмеження швидкості входження вагонів на точкові уповільнювачі.

На станції Секешфехервар, де всю роботу 3 гальмування відчепів на спускній частині i підгіркових коліях виконують точкові уповільнювачі типу Dowty, фактична переробка за добу не перевищує 900 вагонів при наявній переробній спроможності гірки 1200 вагонів на добу. Щорічно виходить 3 ладу і підлягає заміні близько 8 тисяч уповільнювачів i пошкоджується не менше 20 вагонів. Працівники гірки вважають, що це пов'язано 3 конструкцією профілю, недостатністю числа уповільнювачів i їх низькою надійністю у порівнянні $з$ уповільнювачами Thyssen, якими обладнано підгіркові колії станції Ференцварош.

Слід відзначити, що у Росії теж є певний досвід розробки i виготовлення точкових вагонних уповільнювачів. Однак результати їх випробувань не були задовільними. Поряд зі значною вартістю виготовлення і облаштування сортувальних колій дуже коштовною була підтримка надійності роботи цих уповільнювачів, особливо в складних метеорологічних умовах, що стало підставою для припинення їх виробництва.

Застосування на російських залізницях китайських точкових уповільнювачів також не дало позитивних результатів. Так, на станції Ленінград-сортувальний-Московський

Жовтневої залізниці потік їх відмов склав 2-3 на добу. При цьому основна частина уповільнювачів, що вийшла 3 ладу, могла бути відремонтованою тільки в заводських умовах. Крім того, число відмов збільшувалось після переналаштування уповільнювачів на критичні швидкості з настанням холодної пори року. До недоліків їх застосування слід також віднести значний знос неробочої поверхні гребеня колісних пар маневрових локомотивів.

Негативні моменти застосування точкових уповільнювачів мають місце i на станції Забайкальськ Забайкальської залізниці, серед яких значні експлуатаційні витрати на їх обслуговування, зменшення темпу i розмірів переробки за добу, додаткові витрати палива гірковими локомотивами на подолання опору уповільнювачів при перестановці составів, обмеження швидкості руху, неможливість прибирання снігу 3 сортувальних колій існуючими механізмами та ін. 
Закордонний i вітчизняний досвід застосування точкових уповільнювачів дозволив російським фахівцям прийти до висновку, що технологія квазібезперервного регулювання може бути використана на станціях, які проектуються або будуть проектуватися в південних регіонах країни. При цьому у будь-якому випадку слід робити детальне техніко-економічне обгрунтування.

Основними заходами щодо підвищення ефективності сортувального процесу в Росії вважаються механізація сортувальних гірок балочними вагонними уповільнювачами сучасної конструкції і впровадження автоматизованих систем управління сортувальним процесом.

Висновки. Проблема вибору раціональної технології регулювання швидкості скочування відчепів на спускній частині i підгіркових коліях вирішена не в повній мірі. Існуючі технології мають ряд суттєвих недоліків, які впродовж довгого часу вдалося ліквідувати лише частково. Розвиток вказаної технології автори в першу чергу бачать в удосконаленні засобів регулювання швидкості скочування відчепів.

\section{Список використаних джерел}

1. Бобровский, В.И. Исследование влияния длины измерительного участка на скорость роспуска составов [Текст] / В.И. Бобровский // Совершенствование технических устройств и технологии управления процессом расформирования составов на сортировочных горках: Межвуз. сб. научн. тр. - Днепропетровск: ДИИТ, 1986. С. 50-59.

2. Божко, Н.П. Методика определения режимов торможения отцепов при анализе конструкций сортировочных горок [Текст] / Н.П. Божко // Вопросы механизации и автоматизации сортировочного процесса на станциях: Межвуз. сб. научн. тр. - Днепропетровск: ДИИТ, 1983. - Вып. 229/15. - С. 3036.

3. Буянова, В.К. Моделирование на ЭЦВМ процесса роспуска вагонов с сортировочной горки [Текст] / В.К. Буянова // Вестник ВНИИЖТа. - 1965. - № 6. - С. 60-64.

4. Муха, Ю.А. Выбор оптимальных значений регулируемых параметров системы АЗСР ЦНИИ при ее внедрении [Текст] / Ю.А. Муха, В.И. Бобровский // Вопросы механизации и автоматизации сортировочного процесса на железнодорожных станциях: Труды ДИИТа. - Днепропетровск, 1975. Вып. 160/8. - С. 44-64.

5. Муха, Ю.А. Оптимизация режимов торможения скатывающихся отцепов при расформировании составов на сортировочной горке [Текст] / Ю.А. Муха // Вопросы механизации и автоматизации сортировочного процесса на станциях: Труды ДИИТа. - Днепропетровск, 1976. Вып. 181/10. - С. 17-23.

6. Пилипченко, П.А. Моделирование на ЭЦВМ роспуска составов на сортировочной горке [Текст] / П.А. Пилипченко // Вопросы механизации и автоматизации сортировочного процесса на станциях: Труды ДИИТа. - Днепропетровск, 1971. - Вып. 125/7. - С. 33-42.

7. Нагорный, Е.В. Научные основы и разработка комплексной технологии поточной и непрерывной переработки вагонов на сортировочных станциях [Текст]: автореф. дис. ... д-ра техн. наук: спец. 05.22.08 «Эксплуатация железнодорожного транспорта (включая системы сигнализации, централизации и блокировки)» / Е.В. Нагорный. - Харьков, 1994. - 54 с.

8. Берестов, И.В. Оптимизация параметров систем регулирования скорости движения отцепов на путях сортировочных парков [Текст]: автореф. дис. ... канд. техн. наук: спец. 05.22.08 «Эксплуатация железнодорожного транспорта (включая системы сигнализации, централизации и блокировки)» / И.В. Берестов. - Ленинград, 1988. - 24 с.

Рецензент д-р техн. наук, професор Є.С. Альошинський

Квітковська Марія Валеріївна, магістрант, Українська державна академія залізничного транспорту.

Тел. 063-3216732

Kvitkovska Maryna Valeriivna, Master Ukrainian State Academy of Railway Transport. Phone. 063-3216732 